\title{
What did the community health worker do that was helpful? Perceptions from patients with type 2 diabetes
}

\section{Connie H Yan ( $\square$ yan33@uic.edu )}

University of Illinois at Chicago College of Pharmacy https://orcid.org/0000-0003-1467-4666

\section{Aida Rodriguez}

University of Illinois at Chicago Institute for Health Research and Policy

\section{Ben S Gerber}

University of Illinois at Chicago College of Medicine

\section{Lisa K Sharp}

University of Illinois at Chicago College of Applied Health Sciences

\section{Research article}

Keywords: Community health worker, Type 2 diabetes mellitus, Underserved, Summative evaluation

Posted Date: November 2nd, 2019

DOI: https://doi.org/10.21203/rs.2.12372/v2

License: (c) (i) This work is licensed under a Creative Commons Attribution 4.0 International License. Read Full License 
The authors have withdrawn this preprint from Research Square 